\title{
The Development of Teaching Material of IPS Based Geographic Environment of Grade Students of Elementary School
}

\author{
Tyesa Resti Rosavina \\ \{tyesarosavina89@gmail.com\} \\ Elementary Teacher Education Study Program, Faculty of Teaching and Education, Universitas Muria \\ Kudus Gondang Manis PO. BOX 53 Bae, Kudus, Central Java, Indonesia \\ Phone (+62291) 438229, Fax (+62291)437198
}

\begin{abstract}
This study has purpose to develop the teaching materials of IPS based geographical environment to improve the learning outcomes of the fifth grade students of elementary school. This study applied the Research and Development (R \& D) method. The products produced was the teaching materials of IPS based geographical environment. This research was conducted in grade V elementary school in Gebog, Kudus Regency which was determined by using cluster random sampling technique. The data analysis techniques used in this study consists of quantitative descriptive data analysis related to the validity and readability of teaching materials, and to determine the effectiveness of the teaching materials used normalized gain test and test. The results of this study indicated that (1) the results of the validation carried out on teaching materials of IPS based geographical environment were valid to be tested in the learning. Based on this description, it can be concluded that the development of teaching materials of IPS based geographical environment is effective in improving the learning outcomes of the fifth grade students of elementary school.
\end{abstract}

Keywords: Teaching Material, Geographic Environment, IPS

\section{Introduction}

Curriculum development continue to improve the quality of education. Curriculum development is one strategy to improve educational attainment. Student learning activities geared more towards a process approach that students find their own answers to a series of activities that support for the process of the invention will be the answer.

Problems in achieving the objectives contained in the social studies instructional strategies used. This is due to the false notion that social studies learning is rote learning, so the more dominant activity of teachers on students during learning, where teachers are busy teaching materials and students are only required to scrutinize the books that they have. Means of learning is another problem, because the teacher in the not utilize pictures or other media in pebelajaran.

Aligning existing IPS purpose of learning must weigh materials or tools used. Teaching materials that can help stimulate scientific thinking skills are teaching materials that make the students challenged so that students use their thinking skills to solve problems. IPS instructional materials that support for learning is required in aligning existing IPS educational purposes. 
The approach to learning is required in order to make students more active and learn to be more fun. Scientific approach according to Kemendikbud (2013:18) is learning to adopt measures student scientists in building knowledge through scientific methods in the process. The activities in this scientific study carried out by scientists adopt measures in building students' knowledge through scientific methods in the implementation process.

Based on observations and information that in learning social studies in primary Gondosari found several problems, including learning activities in grade V SD 5 Gondosari less held the observations and experiments directly on the material being taught so that students seem just listening to the teacher's explanations and memorizing textbooks, teaching materials used glued to the text material and issues, and less develop student activities directly related to the student environment. Teachers also do not have a teaching material should be in accordance with the characteristics of the students' learning environment, so that the materials used can be more contextual.

The learning process by using existing materials have not been able to bring the maximum increase in learning outcomes evidenced by the many students who have not completed in social studies. Problems of low yields social studies based on the value of UAS Semester 1 at SD 5 Gondosari in the academic year of 2018/2019. From the 23 students, only 8 students, or $35 \%$, which completed the KKM 70 , the lowest score of 40 and the highest grade 82 . Based on the interpretation of study results, the quality of learning still needs to be improved in order to KKM be exceeded. The learning result is still low at 35\% of students who exceeded the completeness KKM showed IPS learning process needs to be fixed.

Seeing these foundations, teaching materials based on the geographical environment in which teaching materials to explore the ability of the students are developing the ability of attitudes, skills and knowledge. Teaching material linking the material studied with the environment as a source of learning and making learning meaningful. Teaching materials developed in this study a student textbook.

\section{Research Methods}

In this study refers to the development of research strategies by Borg and Gall (2003), the present study implementation only to the seventh step (7). This study was performed to improve or develop existing products or create new products by testing the effectiveness of the product produced. Products developed and tested in this study are based teaching materials IPS geographical environment.

Sampling in this study using cluster random sampling technique with a one-stage cluster sampling or making cluster in one step. The sample in this study is elementary that have implemented the curriculum, 2013 in Kudus regency is divided into clusters of districts and sub-districts randomly drawn first, then selected four elementary schools in the District Gebog using random sampling techniques. For the selected SD 3 Karangmalang, SD 1 Kedungsari, SD 10 Gondosari and 2 are located in the district Canyons Gebog.

The field trials conducted in class V Karangmalang SD 3, SD 1 Kedungsari with the number of 32 students as the experimental class. Utility testing conducted experiments teaching material that is pre-experimental model of one group pretest-posttest design according Sugiyono (2015:110-111). 


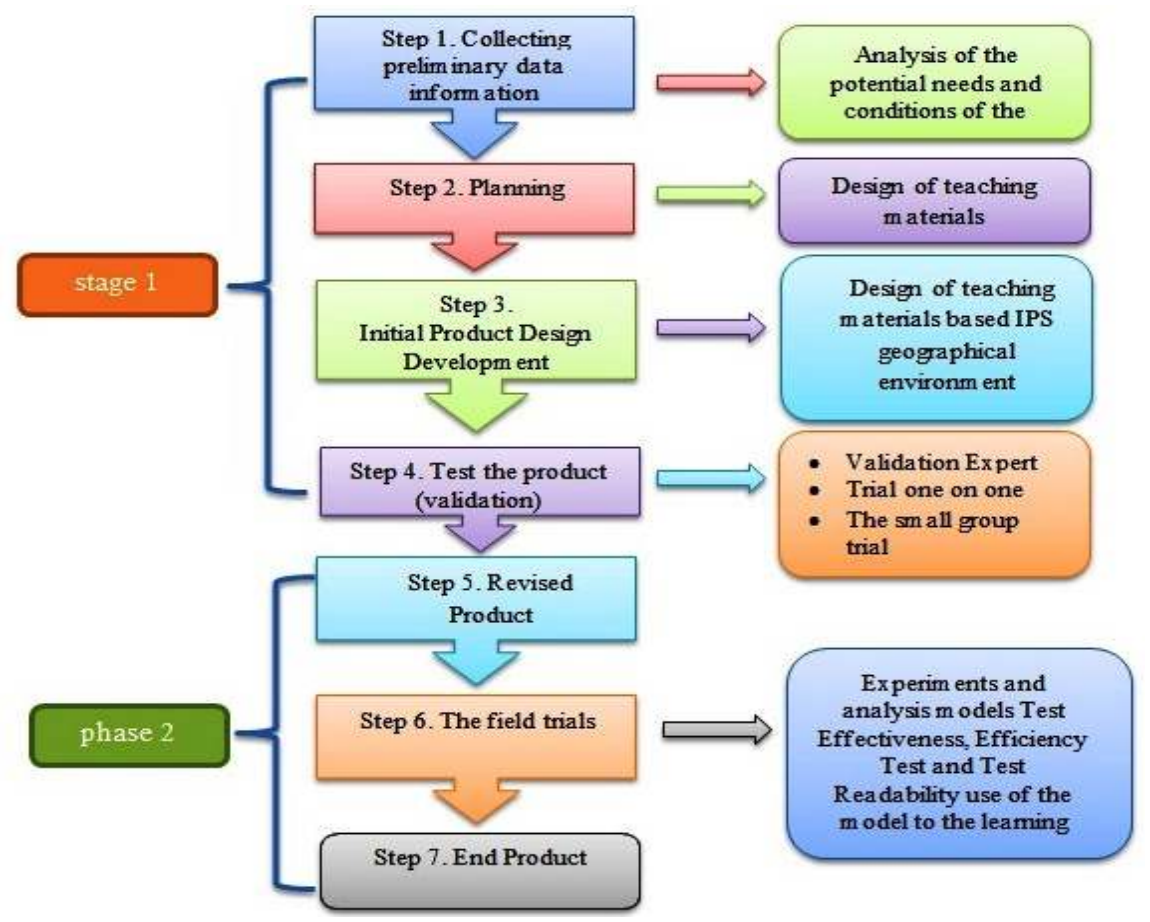

Figure 1. Step Instructional Materials Development Research-based IPS geographical environment Class V SD

\section{Results and Discussion}

\subsection{Result}

Teaching materials developed referring to the 2013 curriculum classes V theme 1 Organ Motion Animals and Humans.The IPS teaching materials developed according to the characteristics of the geographic environment based scientific approach and evaluation tools that make the implementation of student learning is student centered make students active in learning done, so learning more fun and interesting and can improve student learning outcomes. With the scientific stage is expected that students not only master the concepts but also master the skills of scientific thinking in learning.

IPS teaching materials based scientific approach based on geographical environment comprises components scientific approach, this can be seen on stages in the teaching materials. Components in the teaching materials referring to the exposure Hosnan (2014: 39) that the learning activities include measures include: (1) observing (observing), (2) ask (questioning), (3) collect data (experimenting), (4) megasosiasi (associating), (5) communicating (networking).

Validation IPS teaching materials based on the geographical environment thematic learning elementary school class conducted by five people validator. The results validate these materials are presented in Table 1 . 
Table 1. Results of Validation Environment Instructional Materials Geographic-Based IPS

\begin{tabular}{llcl}
\hline No. & validator & The average score & Category \\
\hline 1. & validator 1 & 3.32 & Very good \\
2. & validator 2 & 3.38 & Very good \\
3. & validator 3 & 3.43 & Very good \\
4. & validator 4 & 3.50 & Very good \\
5. & validator 5 & 3.38 & Very good \\
\hline & Average value & 3.40 & Very good \\
\hline
\end{tabular}

Validator assess teaching materials developed with success criteria (very valid) indicates that teaching materials based IPS geographical environment deserves to be implemented in a matter of learning the maps and natural appearance. Assessment conducted by the validator of the teaching materials developed theoretically suggests that the teaching materials are in accordance with the contents, materials and basic competence in material maps and natural features around because by theory, the learning device is said to be valid if aligned with the content, material and competence,

Test legibility legibility by using a questionnaire on 32 students of class V are already using teaching materials. studentclass V Karangmalang SD 3, SD 1 Kedungsari with the number of 32 students as an experimental classasked to complete a questionnaire legibility teaching materials. This questionnaire is about the attractiveness, content and legibility of teaching materials. Details of the calculation results of the questionnaire legibility teaching materials can be seen in Table 2 .

Table 2. Results of the attractiveness and readability Questionnaire Subjects

\begin{tabular}{clcccc}
\hline & & \multicolumn{2}{c}{ Average Percentage } & & S \\
\cline { 2 - 5 } No. & Indicator & D & LA & $15 \%$ & $85 \%$ \\
\hline 1 & Attraction & - & - & $18 \%$ & $82 \%$ \\
2 & Clarity material & - & - & $7 \%$ & $93 \%$ \\
3 & Legibility & - & - & \\
\hline
\end{tabular}

Information:

D : Disagree

LA : Less agree

A : : Agreed

SA : Strongly agree

Seen from Table 2, it is known that $85 \%$ of students strongly agreed that the teaching materials that have been developed by this peneiliti interesting. They can declare these materials attractive for these materials has an attractive overall appearance. Teaching materials are furnished with attractive colors and images so that students become more enthusiastic about learning. In terms of clarity of the material, $82 \%$ of students strongly agree that the teaching materials developed by the researchers has a structure very clear decomposition of the material. Delivery of content in these materials related to everyday life and the geographical environment around the residence of students, making it easier for students to provide direct description. Legibility in terms of teaching materials, as many as $93 \%$ of students strongly agreed that the teaching materials developed is easy to read.

The effectiveness of teaching materials developed are measured using the ratio of a given learning outcome before (pretest) and after (posttest) using teaching materials. Questions used in the form of multiple choice questions and problem descriptions. Number of questions used are 30 questions consisting of 20 multiple choice questions and 10 questions description. 
Validity calculated by correlating the score item with a score total, valid criteria or not an instrument tests compared with rtabel, if rhitung $>$ rtabel the test items as valid (Suharsimi, 2006: 72). Furthermore, the reliability of their multiple choice items which gain coefficient of 0.835 reliabitas test and item descriptions were obtained reliability coefficient of 0.752 , which means high reliability coefficient for high reliability if $0.70<\mathrm{r} 11<0.90$.

The results of calculation posttest data normality about the experimental class are presented in Table 3.

Table 3. Normality Test Results

\begin{tabular}{lccc}
\hline Data & Kolmogorov Smirnov Z & Sig. & Criteria \\
\hline initial conditions & 0.724 & 0,032 & Normal \\
\hline
\end{tabular}

Based on Table 3 obtained significance value $=0.032$. When compared with $a=0.05$, then the Sig $>$ a so that it can be concluded that the results of the experimental class students come from normally distributed population.

The average increase science literacy experimental class students can be seen from the difference between pretest and posttest results. The resulting increase in measured using normalized gain test. Details of the results of individual improvement can be seen in Table 4 .

Table 4. Increased normalized Gain Index

\begin{tabular}{llll}
\hline No. & Improvement Categories & Average Improvement & $\begin{array}{l}\text { The number of } \\
\text { students }\end{array}$ \\
\hline 1 & High & 0.95 & 22 \\
2 & Moderate & 0.68 & 8 \\
3 & Low & 0.29 & 2 \\
\hline Overall Average & $\mathbf{0 , 6 4}$ (medium category) & \\
\hline
\end{tabular}

From these results it can be seen that 22 students has increased to the high category value increase of more than 0.70 , which means a very effective teaching materials. Then 8 students has increased with the medium category with a value increase of between 0.30 to 0.70 which means the effective teaching materials to be used. But the two students has increased in the low category of less than 0.30 , which means less effective teaching materials used for these children. Overall the data can be retrieved from an average improvement of learning outcomes is 0.64 , which means the effective teaching materials developed to improve student learning outcomes.Furthermore, to prove the effectiveness of teaching materials then followed by $\mathrm{t}$ test.

In a hypothesis test, there are some provisions that should be used as guidelines. The provision is that if $\mathrm{t}<\mathrm{t}$ table or significance value $>0.05$, h0 is received, and if $\mathrm{t}>\mathrm{t}$ table or significance value $<0.0$, then $\mathrm{h} 0$ rejected. In this study, researchers used a sample of 32 people, then the value of degrees of freedom $(\mathrm{df})=\mathrm{n}-2=32-2=30$ and $5 \%$ error level to test two parties then can be value $=2.042$ (Priyatno, 2010: 113), The result of the calculation hypothesis test using SPSS version 23 independent sample t test results are shown in Table 5. 
Table 5. The results of T-test analysis

\begin{tabular}{llllllr}
\hline & \multicolumn{5}{c}{ t-test for Equality of Means } \\
\cline { 2 - 6 } & $\mathrm{t}$ & $\mathrm{Df}$ & $\begin{array}{c}\text { Sig. (2- } \\
\text { tailed) }\end{array}$ & $\begin{array}{c}\text { mean } \\
\text { Difference }\end{array}$ & $\begin{array}{c}\text { Std. error } \\
\text { Difference }\end{array}$ \\
\hline Value & $\begin{array}{l}\text { Equal variances } \\
\text { assumed }\end{array}$ & 5.721 & 30 &, 000 & 14.642 & 2,455 \\
$\begin{array}{l}\text { Equal variances not } \\
\text { assumed }\end{array}$ & 5.897 & 52.488 &, 000 & 14.642 & 2.471 \\
\hline
\end{tabular}

Table 5 is known that the data in the study is homogeneous, then to find out the results of hypothesis testing can be seen in the column assumed equal variances. Conversely, if not homogeneous, to find out the results of hypothesis testing can be seen in the column equal variances not assumed. Based on the results of a calculation with SPSS version 23 column assumed equal variances can be seen that the value of $t=5.721$ and significance of 0.000 . From the results of these calculations can be seen that $5.721>2.042$ or $t>t$ table and 0.000 $<0.005$ or significance value $<0.05$. Based on t-test that has researchers have described above, then $\mathrm{HO}$ is rejected and $\mathrm{Ha}$ accepted. So it can be concluded that the teaching material based IPS geographical environment is effectively used in teaching social studies classroom elementary school student.

\subsection{Discussion}

Technology development and rapid information giving a strong influence in many areas of life, one of which is education. Teachers must have the ability to choose from a variety of teaching methods and models and can use a variety of teaching materials to support learning. According to Yeni (2014) forms of learning are carried out through a contextual approach which connects the contents of academic subjects in the context of everyday life to find meaning and methods that promote the active involvement of students in learning. Stages in the steps of the scientific is a learning process to achieve a resolution. The process here is the stages that must be passed so as not necessarily a direct problem can be solved. The basic competencies that students have with the process to meet existing problems can be systematically completed.

Research on the scientific approach carried out by Kruidering, Et al (2013) which revealed that scientific learning experiences can growthe student's attitude, as long as the level of difficulty of properly matched prior knowledge of the learner. Further research is needed to determine how to improve the curriculum of active research to maximize the impact on learners.Teaching materials based on this scientific approach to interact with the geographical environment in line with the students' learning theory developed by Vygotsky which have the idea that learning for children to do in interaction with the social and physical environment.

According to Nasution (2004: 90) the development of teaching materials have several functions including that as a guideline for students to competencies that must be mastered, as a guideline for teachers to direct the learning activities, and as a means of evaluation. Building a high-grade social studies in elementary school (grades 3-5) is essential in order to build a foundation of knowledge to equip students in the secondary school curriculum (Clullo, 2015). To present the learning material in the IPS utilizes concepts, generalizations and construct a learning model that was introduced by Marlin L. Tanck (in Sapriya, 2016: 57-58) as a model of the structure of science. In carrying out learning social studies in elementary school, teachers must pay attention to the characteristics of children of primary school age are still at 
the stage of concrete operations. Teachers should be able to design learning that can arouse the students and connecting material pembelajran with the geographical environment around the child.

These results are consistent with research conducted by Munir (2014) states that the learning device that is about the IPS-based teaching materials around the neighborhood with a constructivist approach emphasizes learning that is sourced from the surrounding students with learning using the constructivist approach. Effective device used to test the n-gain is 0.44 and the percentage of classical completeness $>80 \%$. IPS learning devices with better environment-based approach of the student conventional learning and mastery of the concept of IPS students who take the learning environment based approach better than the students who follow the conventional learning.

\section{Conclusion}

IPS based teaching materials developed by phases of the geographical environment scientific approach which refers to the curriculum in 2013, combined with the geographical environment surrounding students. IPS teaching materials based on the geographical environment proven effective in improving learning outcomes IPS theme 1 Organ Motion Animals and fifth grade first semester

IPS teaching materials based geographical environment cannot only be used with the scientific approach to learning, but teachers should also be able to develop with other innovative learning methods such as Problem Based Learning, Discovery Learning, Project Based Learning, which is effective for improving students' thinking skills.

\section{References}

[1] Borg \& Gall.: Education Research. New York : Allyn and Bacon. (2003)

[2] Clullo, Stephen. : Improving Access to Elementary School Social Studies Instruction (Strategies to Support Student with Learning Disabilities). Teaching Exceptional Children. 103-109. (2015)

[3] Duwi, Priyatno. : Teknik Mudah dan Cepat Melakukan Analisis Data Penelitian dengna SPSS. Yogyakarta; Gava Media. (2010)

[4] Kemendikbud.: Pedoman Diklat Guru dalam Rangka Implementasi Kurikulum 2013. Jakarta : Kemendikbud. (2013)

[5] Kruidering-Hall., Vereijken, M.W.C., Jong, P.G.M., Beaufort, A.J., \& Dekker, F.W.: Scientific education early in the curriculum using a constructivist approach on learning. Perspect Med Educ, 6 (2): 209-215. (2013)

[6] Nasution, S.: Metode Penelitian Naturalistik-Kualitatif. Bandung: Tarsito Agung. (2004)

[7] Sapriya.: Pendidikan IPS. Bandung: Remaja Rosdakarya. (2016)

[8] Sugiyarti, Iis Yeni.: Pengembangan Perangkat Pembelajaran IPS dengan Pendekatan Kontekstual Berbantuan Peta Pikiran Pada Materi Persebaran Sumber Daya Alam di Lingkungan Setempat. Tesis. Semarang: Program Pascasarjana UNNES. (Unpublish). (2014)

[9] Sugiyono.: Metode Kuantitatif, Kualitatif, dan R\&D. Bandung: Alfabeta. (2015)

[10] Suharsimi, A.: Dasar-Dasar Evaluasi Pendidikan. Bandung: Bumi Aksara. (2006) 